\title{
Editorial
}

\section{Suicide; A Manic Engulfing Youth}

\section{Sadaf Ahmed, Shamoon Noushad \& Salman Sheikh}

Advance Educational Institute \& Research Center

Corresponding Author: sadaf@ aeirc-edu.com

Whoever attempts to commit suicide and does any act towards the commission of such offence shall be punished with simple imprisonment for a term which extends to one year or with fine or both". (Major criminal Acts, PPC-1860 p; 209 Ed.2005). It is always disturbing to know that so many adolescents committing suicide in such quick succession, one can only wonder about the frolic snuffed so callously.

Youth is a more exposed group that is daily opened to the stress in Pakistan and opt for risky behaviors. Though the figures are alarming still more than half of cases go unreported due to reluctant families to register the case as attempted suicide. World Health Organization estimated that over 15,000 suicides get committed in Pakistan; however Psychiatrist estimated it around 7,000 annually.

Other than this there are approximately 150,000 reported cases of attempted suicides by people under the age of 30 years (WHO, 2016). There is by all accounts an expansion in suicides among youngsters these days.

There was the miserable loss of a 27-yearold student of bachelors who set himself ablaze on the grounds that he wasn't permitted to give an exam paper. Essentially, the tragic instance of the 17year-old Saqiba Kakar, who ingested toxic pills after the school central supposedly declined to send her examination forms to the board. (Syed Ali Shah, 2016). We had likewise run over the unfortunate demise of Suleman, 14, who shot himself after the guardians of the young lady he loved, rejected his marriage proposal. (Riaz Ahmed, 2016). Furthermore, the rundown goes on:

- A 15-year-old student shot himself to death in the federal capital on Monday after he fell in love with his teacher. (Samaa Web Desk, 2017).

- Yaqoob shot himself dead with a pistol at his home after his father, Kaleem, scolded him for not taking interest in his studies. (Zofeen T. Ebrahim, 2012).

- Eighteen-year-old Khursheed, was a student at the Islamabad Model College for Boys, Khursheed had apparently refused to take some entry tests, on which his father had scolded him. (Web Desk, 2012).

- Shan, 17, a resident of Gharibabad near Khanpur, swallowed poison. He did so after his parents stopped him from spending time with friends and concentrate on his studies instead. (The Express Tribune, 2012).

- A class six student allegedly committed suicide inside his house in Nazimabad on Tuesday night. He was 13 years old he apparently committed suicide by hanging himself by the ceiling fan out of fear of his parents as he perhaps failed at school. (The Express Tribune, 2012).

- In September of 2013 at the age of 12, Rebecca jumped to her death from atop an abandoned cement silo. The girls had apparently been spurred by jealousy over Rebecca's former involvement with a local boy. These messages included "Why are you still alive?" and "Go kill yourself." (Jim Goad, 2015). 
- A 13 year-old boy committed suicide inside his house, he hanged himself from ceiling fan In his suicide note, he wrote that he was fed up of hostel, where he was often subjected to severe punishment at the hands of a teacher he left unnamed. (The Express Tribune, 2012)

- On April 16th, 2010 a 21 year- old medical student from Chitral hung himself from ceiling fan of his dorm room. (Yusra Salim, 2016).

- 14 year-old schoolboy suicide in Peshawar, he shot himself after the parents of the girl he loved, declined his marriage proposal. The girl's parents maintained that she was too young to get married. (Riaz Ahmed, 2016).

- On April 21st, 2016 the nursing student allegedly hanged himself from the ceiling fan on Wednesday night; he was from Gilgit and had been studying at nursing school since 2014. (Yusra Salim, 2016).

- On May 11th, 2014 a teenaged girl and a boy in his twenties, both were the students of university, they committed suicide by eating poison, and their bodies were mysteriously found dead in the boy's car parked in the parking area. (Dunya News, 2016).

- On June 19th, 2016 a young man and women recently graduates of a private university in Hyderabad, committed a suicide by eating poison. The family says the couple wanted to marry but their parents were opposed to it (Express tribune, 2016).

- On April 11th, 2016 a final year medical student committed suicide after a university refused to allow him to appear in the final year exam for being late. (Dunya News , 2016)

- On September 1st, 2015 teen kill's girlfriend, commits suicide (in school) because parents weren't ready to accept relationship. (Web Desk, 2015).

- A university student tried to commit suicide by self- immolation, the 24 year- old boy tried to set himself on fire by sprinkling

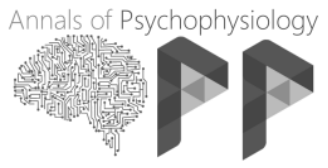

kerosene all over his body. The burn injuries cover 90 percent of his body, (Express Tribune, 2014).

- A teenage girl from Baluchistan's Killa Saifullah district committed suicide after college principal refused to send her examination form to the intermediate education board. (Syed Ali Shah, 2016).

- A young teenage couple has allegedly committed suicide by hanging themselves on a tree in the Cholistan desert after they were not allowed by their families to marry. (Srafraz Ali, 2017).

- A university student has committed suicide, his mother asked him to go to university but he did not want to continue his studies. As his mother scolds him on his refusal, he hanged himself with the ceiling fan. (Pakistan Today, 2017)

- A young 14 year old boy, $9^{\text {th }}$ class student committed suicide in his hostel room by hanging himself with the ceiling fan for unknown reason. (Pakistan Today, 2017).

- A girl student of "A" levels committed suicide by shooting her. The reason behind the suicide could not be ascertained. (Pakistan Observer, 2017).

- A young teenage boy committed suicide after he flunked the entry test of private university. (Atiq Ali, 2016).

- A 22 year old girl aspirant for admission on sport basis in university, committed suicide for domestic reason at girl's hostel, she hang herself with the ceiling fan. (Salim Ahmed, 2016).

The principal cause is lack of communication between parents and teenagers. Sometimes the kids are going through mixed emotions and the fear to discuss issues with adults or peers. Anyone with emotional imbalances can take such drastic steps. The foundation of each heinous is financial discrepancies. The parental strain on their high school youngsters to push for the expert universities

Sadaf Ahmed 
and organizations is a sort of future protection, which unleashes the intellectual pressure on the youngsters; however, they can't confront the ferocious conflicts within the community without appropriate facilities. This is the basic explanation for the young people to go for suicidal results to free themselves. For future research, then, it will be interesting to explore the interaction there may between people with a predisposition to suicide, i.e. where clinical depression is present, and the pressures on families that arise from increasingly competitive economic environments. The interaction between these sorts of pressures and the presence of clinical depression may be a cocktail that is increasingly lethal over time.

\section{References}

- Atiq Ali (2016, November 25). Suicide.

Retrieve from: http://pakobserver.net/suicide/

- Dunya News (2016, April 21). Karachi: Aga Khan University's student commits suicide. Retrieve from: http://dunyanews.tv/en/Pakistan/333303Karachi-Aga-Khan-Universitys-studentcommits-sui

- Dunya News (2016, August 4). Sargodha: Girl, boy commit suicide over love marriage refusal from parents. Retrieve from:

http://dunyanews.tv/en/Pakistan/347754Sargodha-Girl-boy-commit-suicideover-love-marri

- Jim Goad (2015, April 22). A pervert leaked a topless photo of Amanda Todd, then a group of girls bullied her until she ended up taking her own life. Retrieve from: https://thoughtcatalog.com/jimgoad/2015/04/15-teen-bullying-cases/

- Pakistan Observer (2017, August 2). 'A' levels girl student commits suicide. Retrieve

from: http://pakobserver.net/a-levels-girlstudent-commits-suicide/

- Pakistan Today (2017, January 18). Student commits suicide. Retrieve from: https://www.pakistantoday.com.pk/2017 /01/18/student-commits-suicide-2/

- Pakistan Today (2017, January 18). University student commits suicide. Retrieve from: https://www.pakistantoday.com.pk/2017 /04/25/university-student-commitssuicide/

- Riaz Ahmed (2016, February 27). 14year-old schoolboy commits suicide in Peshawar over marriage refusal. Retrieve from:

https://tribune.com.pk/story/1055453/14year-old-schoolboy-commits-suicide-inpeshawar-over-marriage-refusal/

- Salim Ahmed (2016, October 26). Girl commits suicide in PU hostel. Retrieve from: http://pakobserver.net/girlcommits-suicide-in-pu-hostel/

- Samaa Web Desk (2017, January 16). Islamabad teen commits suicide after falling in love with teacher. Retrieve from:https://www.samaa.tv/pakistan/201 7/01/islamabad-teen-student-commitssuicide-after-falling-in-love-withteacher/

- Sarfraz Ali (2017, May 27). Cholistani teenage couple commits suicide together after family disapproval. Retrieve from: https://en.dailypakistan.com.pk/pakistan/ cholistani-teenage-couple-commitssuicide-together-after-familydisapproval/

- State of Human Rights. (2013). Human Rights Commission of Pakistan. ISBN978-969-8324- 61-2

- Syed Ali Shah (2016, May 31). Student suicide case: Arrest warrant issued for principal, clerk arrested. Retrieve from: https://www.dawn.com/news/1261856 
- The Express Tribune (2012, May 28). Suicide: 17-year-old swallows poison. Retrieve from: https://tribune.com.pk/story/385086/suic ide-17-year-old-swallows-poison/

- The Express Tribune (2012, May 30). Fear of failure: Class VI student commits suicide. Retrieve from: https://tribune.com.pk/story/385947/fear -of-failure-class-vi-student-commitssuicide/

- The Express Tribune (2012, May 30). Tangled in misery: To evade punishment, schoolboy ends his life. Retrieve from: https://tribune.com.pk/story/385829/tang led-in-misery-to-evade-punishmentschoolboy-ends-his-life/

- The Express Tribune (2014, March 23). Self- immolation: University student attempts suicide. Retreive from: https://tribune.com.pk/story/686140/selfimmolation-university-student-attemptssuicide/

- The Express Tribune (2016, June 20). Couple's bodies found in car in possible suicide. Retrieve from: https://tribune.com.pk/story/1125934/my sterious-circumstances-couples-bodiesfound-car-possible-suicide/
- Web Desk (2012, May 30). 18-year-old student commits suicide in Islamabad. Retrieve from: https://tribune.com.pk/story/386268/18year-old-student-commits-suicide-inislamabad/

- Web Desk (2015, September 1). Teenage couple carry out suicide pact during school assembly in Karachi. Retrieve from:https://defence.pk/pdf/threads/teen age-couple-carry-out-suicide-pactduring-school-assembly-inkarachi.395189/

- World Health Organization. (2016). World Health Statistics 2016: Monitoring Health for the SDGs Sustainable Development Goals. World Health Organization.

- Yusra Salim (2016, April 21). AKU student commits suicide. Retrieve from: https://tribune.com.pk/story/1089158/ak u-student-commits-suicide/

- Zofeen T. Ebrahim (2012, June 8).The alarming rise of teenage suicides in Pakistan. Retrieve from: https://www.dawn.com/news/724902 